\title{
THE VALUE AND ALLOCATION OF TIME IN RURAL BOTSWAN.
}

\author{
Eva MUELLF:R* \\ Universi y of Michigan, Ann Arbor, MI 48104-2590, US.A \\ Received November 1982, final vers on received May 1983
}

Time use data indicate that there is substantial surpl is labor in rural areas of Botswana, with the incidence of underutilizition varying by age, sex, and asset position. Time allocations are influenced by economic incentives, i.e., income and oroductivity effects. The more productive capital the household has, the more productive wcrk its members perform, particularly its children. The positive prodictivity effect of capital on economic work somewhat outweighs its negative income cffect. Time allocations also are consirained by a culturally determined division of labor by age and sex, which however shows some flexibility at the margin.

\section{Introduction}

The purpose of this paper is to analyze the determinants of time allocation by rural households in Botswana and to consider some of the economic implications of time use patterns. Among various time uses, economic pursuits are of greatest interest, since the $y$ are major determinants of income level and income distribution. ${ }^{1}$ Indeed, the main reason for the collection of time use data in rural Botswana was the Government of Botswana's desire to obtain detailed information about the economic activities which generate income in the rural sector. A related objective was to explore the proposition that there is a substantial pool of unclerutilized labor in the rural areas. Traditionally the economic activities of rural populations have been studied by using data on labor force participation, employment, and unemployment. The time use data extend these measurements by providing infor nation on hours worked for wayges and in family enterprises, i.e., on the extent or duration of labor utilization.

Other large-scale statistical time use : tudies which have been cn aducted in LDC, pertain largely ti) Asian countrie:; [e.g., Boulier (1977), Da Vanzo and Lee (1983), De Tray (1982), Evenson, Fopkin and King-Quizon (1979), Hart

*I am indebted to a num er of people who have helped me with this paper, especially Dov Chernichovsky, Fran Heitz, nd Barbara Watanabe.

${ }^{1}$ The term income is used in this paper to in lude income in kind. The terms market work, economic work, economic pursuits, and labor refer to activities which contribute to GNP, including unpaid fanily labo ${ }^{-}$and work that ear is income in kind. Housework is a separate and distinct time use category. 
(1981)]. Presumably, time use patterns vary from one economic and cultural setting to another. Rural Botswana is typical of areas in Ceniral and West Africa where rainfall is $s_{r a}^{r}$ rse and uncertain. While the scarcity of water severely limits the potential for crop production, cattle grazing is more drought resistant. Thus there is a tendency to emphasize animal husbardry in agriculture and to increase herd size when possible. Labor dernand for crop production is relatively low. Rural Botswana also is an extreme case of African areas which experience very high levels of male out-migration. Traditionally, rural surplus labor has gone to the mines in South Africa. In the recent period demand for migrant workers has begun to decline in South Africa but has increased in urban indu:tries in Botswana.

The theoretical framewcrk on which this paper is based assume; that time allocations are responsive to economic incentives. That is, they are expected to be sensitive to income and price-of-time (or productivity) effects. Methodologicaily, this paper differs from previous studies with a similar the retical orientation in two respects. First, it attempts to estimate the marginal contribution to income generation of family time inputs, disaggregated by age and sex. Secondly, in the time use analysis the price of time is measured, not by market wages (actual or estimated), but by the productivity of time in self-employment as determined by inputs of human and non-human capital plus such characteristics as age and location. The appropriateness of this approach will be justified in the body of the paper.

In addition to studying income and price-of-time effects on time allocation we shall examine how the age/sex composition of the househoid and its size affect its time allocation and its labor supply. This analysis throws some light on the opportunity cost of schoo! attendance and the value of childre's labor as a motive for high fertility. Finally, the paper recognizes that a culturally determined division of labor by age and sex constrains household choice. A further purpose of this paper is to clarily the relative role of economic and institutional influences on time use decisions.

Five sections follow this introduction. The second section discusses the data and briefly describes time use patterns in rural Botswana. Then some conceptual problems are addressed in the third section. Productivity of time and the determinants of time allocation are analyzed in seciions four and five respectively. Conclusions are diferred to the end and are presented in section six.

\section{Data and setting}

This paper is based on the Rural Income Distribution Survey (RIDS) conducted by the Government of Botswana in 1975. Inicome data were collected by visiting each household in 12 consecutive months. The time allocation data pertain to the day prior to the interview ard were obtained only in rounds, 3, 5, 7, 9 and 11 of the twelve monthly survey rounds. 
Interviews were s read over all days of the week, including Saturdays and Sindays. All persons in the housei old, 6 years of age and above, were asked to recall the previous day's accivities and the approximate amount of time each activity occupied in chronological order from the time they got up in the morning until they retired at nigh1; mealtime was omitted.

The period not covered by the tiric use study, February through April, falls into the busy season. Thus the time frame of the study leads to some understatement of economic activities Further, some mirol activities seem to be underreported in the survey, implying some overstatement of leisure time. On the other hand, 'rest stops' during working hours and housework or a leisurely work pace could lead to a considerable overstatement of working hours.

The data presented in this paper are based on pooled observations for all five visits and thus average out :easonal variations. Non-response was negligible; for about 100 households the time use information was too incomplete to be usable for analysis. This exclusion is erquivalent to a nonresponse rate of 10 percent. The 957 households remaining in the sample contain about 4,600 individuals over 6 years old. ${ }^{2}$

Undoubtedly, people in rural Botswana do not keep precise track of time during their daily activities; they merely know that they devoted half of the day to one activity and half to another. In cases where the respondent reported time use in terms of fractions of a day, the interviewers were instructed to assume a day of 12 hours (roughly the time from sunrise to sunset). Therefore the distribution of time between activities probably is more reliable than the absolute amount of time spent on activities. For this reason the descriptive tables show percentage distributions, rather than mean amounts of time spent on various activities.

Tables 1 and 2 present an overview of time use within age groups, for men and women respectively. Patterns of time use vary sharply by age and sex. Animal husbandry is predominantiy a male activity, and men are also more involved in wage labor than women. Women spend the largest part of their income earning time on crop cultivation, but this is not exclusively a female activity. Men participate in certain essential operations such as land clearing, plowing and planting.

Women and girls do most of the gathering, and they engage to a lesser extent in other economic activities. Their most time-consuming activities are, however, housework, child care and fetching water. In all, adult men spend about 75 percent more time on income earning activities than adult wornen. Despite this, adult wonen still reported on the average nearly 25 percent less

\footnotetext{
${ }^{2}$ The household was defined to consist of its de facto members only. Individuals had to be present at 7 or more of the 12 survey visils to qualify as household members for purposes of the time use analysis. Incomes of absent miguants were included only insofar as they were remitted to the household.
} 
Table 1

Males: Distribution of activity time by age."

\begin{tabular}{|c|c|c|c|c|c|c|c|c|c|}
\hline \multirow[b]{2}{*}{ Activities } & \multicolumn{7}{|l|}{ Age } & \multirow[b]{2}{*}{$60+$} & \multirow{2}{*}{$\begin{array}{l}\text { All } \\
\text { males }\end{array}$} \\
\hline & $7-9$ & $10-14$ & $15-19$ & 20.29 & $30-39$ & $40-49$ & $50-59$ & & \\
\hline & \multicolumn{8}{|c|}{ Percentage distribution of total time } & \\
\hline $\begin{array}{l}\text { Crop husbundry } \\
\text { Animal husbandry } \\
\text { Wage labor } \\
\text { Trading vending, processing } \\
\text { Hunting or gathering }\end{array}$ & $\begin{array}{r}2.1 \\
22.3 \\
0.4 \\
0.1 \\
1.2\end{array}$ & $\begin{array}{r}3.0 \\
258 \\
0.4 \\
0.1 \\
1.6\end{array}$ & $\begin{array}{r}3.5 \\
23.9 \\
2.0 \\
0.7 \\
1.9\end{array}$ & $\begin{array}{r}5.2 \\
12.5 \\
12.2 \\
0.9 \\
2.0\end{array}$ & $\begin{array}{r}6.1 \\
15.1 \\
8.1 \\
1.0 \\
2.6\end{array}$ & $\begin{array}{r}9.1 \\
106 \\
7.4 \\
1.9 \\
3.0\end{array}$ & $\begin{array}{r}7.7 \\
12.3 \\
5.5 \\
1.1 \\
1.9\end{array}$ & $\begin{array}{r}10.5 \\
9.2 \\
1.9 \\
1.6 \\
2.3\end{array}$ & $\begin{array}{r}5.4 \\
18.7 \\
4.0 \\
0.8 \\
2.0\end{array}$ \\
\hline All incorme earning activities & 26.2 & 33.9 & 32.6 & 32.9 & 32.8 & 32.1 & 28.4 & 25.6 & 36.8 \\
\hline $\begin{array}{l}\text { Repairing, new building } \\
\text { Fetching water } \\
\text { Child care } \\
\text { Housework }\end{array}$ & $\begin{array}{l}0.8 \\
1.6 \\
3.8 \\
2.8\end{array}$ & $\begin{array}{l}0.5 \\
2.3 \\
1.7 \\
4.4\end{array}$ & $\begin{array}{l}1.6 \\
2.2 \\
0.9 \\
5.1\end{array}$ & $\begin{array}{l}1.9 \\
1.9 \\
0.5 \\
5.2\end{array}$ & $\begin{array}{l}2.6 \\
1.7 \\
0.5 \\
3.0\end{array}$ & $\begin{array}{l}3.3 \\
1.4 \\
0.1 \\
4.0\end{array}$ & $\begin{array}{l}5.6 \\
0.2 \\
0.0 \\
2.2\end{array}$ & $\begin{array}{l}3.7 \\
1.1 \\
0.2 \\
2.4\end{array}$ & $\begin{array}{l}2.1 \\
1.7 \\
1.2 \\
3.8\end{array}$ \\
\hline All housekeeping activitie. & 8.9 & 8.9 & 9.8 & 9.6 & 7.8 & 8.7 & 8.0 & 7.3 & 8.7 \\
\hline Schooling & 11.1 & 13.7 & 9.3 & 1.1 & 0.3 & 0.6 & 0.3 & 0.1 & 6.1 \\
\hline $\begin{array}{l}\text { Illness \& health care } \\
\text { Meetings } \\
\text { Leisure }\end{array}$ & $\begin{array}{r}1.5 \\
0.0 \\
52.3\end{array}$ & $\begin{array}{r}1.5 \\
0.0 \\
42.0\end{array}$ & $\begin{array}{r}2.6 \\
0.1 \\
46.2\end{array}$ & $\begin{array}{r}3.0 \\
0.4 \\
53.1\end{array}$ & $\begin{array}{r}2.5 \\
1.3 \\
55.3\end{array}$ & $\begin{array}{r}2.9 \\
2.0 \\
53.6\end{array}$ & $\begin{array}{r}5.3 \\
2.7 \\
55.3\end{array}$ & $\begin{array}{r}8.4 \\
2.9 \\
55.7\end{array}$ & $\begin{array}{r}3.2 \\
0.9 \\
50.3\end{array}$ \\
\hline All non-work activities & 53.8 & 43.5 & 48.8 & 56.5 & 59.1 & 58.5 & 63.2 & 67.0 & 54.4 \\
\hline All activities & 100.0 & 100.0 & 100.0 & 100.0 & $1 \times 0.0$ & 100.0 & 100.0 & 100.0 & 100.0 \\
\hline
\end{tabular}

'Based on five ror $\eta$ ts of interviewing. A varying number of people in each category answered the activity questios in the iive rounds. Only daytime activities have been covered; i.e., sleeping at night is excluded. sll tables based on RIDS.

leisure than men, due to their involvement in hrusekeeping and child care, in addition to econonnic work. ${ }^{3}$

Men and women aged 60 and over report significant amounts of time in income eaming activities. On the whole they seem to be a considerable asset to the hous:hold, or at least less of a burden than is often supposed.

Boys seen to be heavily involved in income earning activities even before they are 10 years old, and at ages 10-14 they spend as much time on income earning activities as adult males. The job of taking care of the small stock in the household falls in large part to the younger boys, while older boys (10 and over) herd and water the cattle.

Girls provide some help in the fields and in caring for the smaller animals but their main contribution consists of chilo care and housework, to which they devote substantial amounts of time. Girls report slightly more school tours than boys but over the year children of both sexes allocate at least twice as much time to market and housework as they do to schooling. It

\footnotetext{
${ }^{3}$ For a more detailed discussion and additional data on the sexual division of labor, set: Kossoudji and Mueller (1983) and Bond (1974).
} 
Table 2

Fenales: $D$ stribution of activity time by age *

\begin{tabular}{|c|c|c|c|c|c|c|c|c|c|}
\hline \multirow[b]{2}{*}{ Activities } & \multicolumn{8}{|l|}{ Age } & \multirow{2}{*}{$\begin{array}{l}\text { All } \\
\text { female }\end{array}$} \\
\hline & $7-9$ & $10-14$ & $15-19$ & $20-29$ & 30-39 & $40-49$ & $50-59$ & $60+$ & \\
\hline & \multicolumn{8}{|c|}{ Percentage distribution of total time } & \\
\hline $\begin{array}{l}\text { Crop husbandry } \\
\text { Animal husbandiy } \\
\text { Wage labor } \\
\text { Trading, vending, processinf } \\
\text { Hunting or gathering }\end{array}$ & $\begin{array}{l}: .4 \\
: .2 \\
0.1 \\
0.0 \\
1.6\end{array}$ & $\begin{array}{l}3.5 \\
3.8 \\
0.8 \\
0.5 \\
2.6\end{array}$ & $\begin{array}{l}6.0 \\
2.1 \\
2.1 \\
1.5 \\
2.8\end{array}$ & $\begin{array}{l}8.6 \\
1.5 \\
2.0 \\
1.7 \\
2.5\end{array}$ & $\begin{array}{r}10.2 \\
1.2 \\
1.1 \\
3.0 \\
2.7\end{array}$ & $\begin{array}{r}12.8 \\
0.9 \\
1.7 \\
1.6 \\
2.5\end{array}$ & $\begin{array}{r}13.4 \\
0.5 \\
0.8 \\
1.8 \\
2.8\end{array}$ & $\begin{array}{r}11.5 \\
0.5 \\
0.1 \\
1.2 \\
2.3\end{array}$ & $\begin{array}{l}8.0 \\
1.9 \\
1.2 \\
1.4 \\
2.5\end{array}$ \\
\hline All income earning activities & 7.2 & 11.2 & 14.4 & 16.4 & 18.1 & 19.5 & 19.2 & 15.6 & 15.0 \\
\hline $\begin{array}{l}\text { Repairing, new building } \\
\text { Fetching water } \\
\text { Child car. } \\
\text { Housework }\end{array}$ & $\begin{array}{r}0.5 \\
4.8 \\
0.5 \\
9.5\end{array}$ & $\begin{array}{r}0.8 \\
6.3 \\
5.5 \\
155\end{array}$ & $\begin{array}{r}2.2 \\
7.2 \\
3.4 \\
20.8\end{array}$ & $\begin{array}{r}3.2 \\
7.8 \\
6 . ? \\
22.3\end{array}$ & $\begin{array}{r}4.3 \\
74 \\
3.5 \\
195\end{array}$ & $\begin{array}{r}5.5 \\
6.4 \\
1.9 \\
18.7\end{array}$ & $\begin{array}{r}5.8 \\
5.8 \\
1.5 \\
18.4\end{array}$ & $\begin{array}{r}4.9 \\
4.4 \\
1.5 \\
13.5\end{array}$ & $\begin{array}{r}3.1 \\
6.5 \\
4.5 \\
17.8\end{array}$ \\
\hline All housekeeping activities & 25.3 & 28.3 & $34 . i$ & 39.5 & 34.7 & 32.6 & 31.5 & 24.3 & 32.0 \\
\hline Schooling & 14.4 & 17.4 & 8.3 & 1.2 & 0.3 & 0.3 & 0.2 & 0.1 & 5.8 \\
\hline $\begin{array}{l}\text { Illness \& healt. care } \\
\text { Meetings } \\
\text { Leisure }\end{array}$ & $\begin{array}{r}1.1 \\
0.0 \\
52.0\end{array}$ & $\begin{array}{r}2.0 \\
j .2 \\
41.0\end{array}$ & $\begin{array}{r}3.6 \\
0.4 \\
39.2\end{array}$ & $\begin{array}{r}4.6 \\
0.3 \\
38.0\end{array}$ & $\begin{array}{r}5.6 \\
0.6 \\
40.6\end{array}$ & $\begin{array}{r}6.3 \\
0.9 \\
40.5\end{array}$ & $\begin{array}{r}6.4 \\
0.4 \\
42.3\end{array}$ & $\begin{array}{r}8.6 \\
0.5 \\
50.9\end{array}$ & $\begin{array}{r}4.5 \\
0.4 \\
42.2\end{array}$ \\
\hline All non-work activities & 53.1 & 43.1 & 43.1 & 42.9 & 46.9 & 47.7 & 49,1 & 59.9 & 47.1 \\
\hline All activities & 100.0 & 100.0 & 100.0 & 100.0 & 100.0 & 100.0 & 100.0 & 100.0 & 100.0 \\
\hline
\end{tabular}

'Based on five rounds of interviewing. A varying number of people in eact category answered the activity questions it the five rounds. Only daytime activities have been covered; i.e., sleeping at night is excluded.

appears that childre, make a substantial economic contribution to the household by workin; and by relieving women of some domestic duties.

A number of studies [Byerlee and Eicher (1979), Cleave (1970)] reporting labor inputs to agriculture in Africa have shown surprisingly low levels of manhours worked per year. The Botswana data for adult males conform to this pat ern. Some ot servers have attributed this phenomenon to the marked seasonality of agricultur!! work. W'hen the time use data are examined by season of the year, it appears that men allocate about 60 percent more tim: to income earning ativities during the kusy than during the slack season, and boys about 100 percent more. The seasonality of time use is even nore pronounced for wom $n$ and girls because :rop production is largeiy 'women's work. Housework tume seems to be quice insensitive to the seasonality in labor demand Consequently, adults gain considerable leisure time during the slack work season. Thildren's time is shifted to schooi attendance in the slack season (vacations coincide roughly with the busy work season).

Some knowledgealle observers belicve that Bolswana is suffering from a great deal of underernployment [Lipton (1978)]. A comparison of male time J.D.E. $N$ 
use in large and small villages and in Baralong Farms - the major commercial farming area in Botswana - throws some light on this issue. The data for Baralong Farms show how time is used in an area with relatively high labor demand and relatively high rates of return to agricultural production. Men and boys in Baralong Farms work substantially more hours then men in other places. If men and boys in Baralong Farms are not over worked, people in the otiver villages might prefer less leisure and more productive work opportunities.

Wage labor makes up a s.nall fracticn of economic work in rural areas, as indicated by tables 1 and 2 . This finding is borne out by the data in table 3 which reveal that there is practically no wage labor market for children under 15, and that for young people 15-19 wage employment is rare and of short duration. ${ }^{4}$ About 20 percent of the women age 20-59 worked for wages at some time during the survey year, but fewer than 6 percent had jobs which lasted 180 days or more during the year. In comparison, about 30 percent of males aged 20-59 had wage jobs, including about 15 percent with durations in excess of 180 days. There is no appreciable seasonality in wage labor.

When one compares the total time contributed to economic work by adult men, women and children, the striking fact emerges that, because of the high

Table 3

Number of days engaged in wage labor per year by age and sex.

\begin{tabular}{|c|c|c|c|c|c|c|c|c|c|}
\hline \multirow{2}{*}{$\begin{array}{l}\text { Days worke! } \\
\text { for wages }\end{array}$} & \multicolumn{8}{|l|}{ Age } & \multirow[b]{2}{*}{ Total } \\
\hline & $7-9$ & $10-14$ & $15-19$ & $20-29$ & $30-39$ & $40-49$ & $50-59$ & $60+$ & \\
\hline \multicolumn{10}{|l|}{ Moles } \\
\hline 0 & 99.3 & 96.0 & 86.4 & 68.3 & 71.6 & 70.8 & 68.7 & 8.3 .6 & 83.7 \\
\hline $1-29$ & 0.0 & 1.4 & 4.3 & 5.3 & 6.9 & 7.1 & 70 & 4.7 & 3.9 \\
\hline $30-99$ & 0.7 & 2.1 & 7.0 & 6.1 & 5.5 & 6.0 & 6.2 & 4.5 & 4.4 \\
\hline $100-179$ & 0.0 & 0.2 & 1.2 & 3.4 & 2.9 & 2.4 & 3.2 & 1.0 & 1.5 \\
\hline $180-259$ & 0.0 & 0.1 & 0.8 & 6.9 & 2.9 & 4.5 & 3.2 & 1.2 & 2.1 \\
\hline $260+$ & 0.0 & 0.1 & 0.3 & 10.0 & 10.2 & 9.2 & 11.6 & 4.9 & 4.5 \\
\hline Total & 100.0 & 100.0 & 100.0 & 100.0 & 100.0 & 100.0 & 100.0 & 100.0 & 100.0 \\
\hline \multicolumn{10}{|l|}{ Females } \\
\hline 0 & 99.8 & 95.3 & 87.8 & 81.8 & 78.8 & 79.3 & 82.4 & 92.9 & 87.3 \\
\hline $1-29$ & 0.2 & 0.8 & 3.2 & 4.7 & 8.2 & 7.8 & 8.8 & 3.9 & 4.3 \\
\hline $30-99$ & 0.0 & 2.2 & 6.0 & 6.8 & 7.0 & 8.4 & 6.8 & 1.8 & 4.9 \\
\hline $100-179$ & 0.0 & 1.5 & 2.3 & 1.4 & 2.2 & 1.3 & 0.4 & 1.2 & 1.4 \\
\hline $180-259$ & 0.0 & 0.2 & 0.3 & 2.4 & 1.2 & 0.2 & 0.9 & 0.0 & 0.8 \\
\hline $260+$ & 0.6 & 0.0 & 0.5 & 2.9 & 2.6 & 3.0 & 0.6 & 0.3 & 1.3 \\
\hline Total & 100.0 & 100.0 & 100.0 & 100.0 & 100.0 & 100.0 & 100.0 & 100.0 & 100.0 \\
\hline
\end{tabular}

\footnotetext{
${ }^{4}$ This table is based on more extensive clata on number of davs engaged in wage labor each month, obtained in the 12 monthly interviews concerning he usehold income.
} 
birth rate and the high male out-migration rate, men between the ages of 20 and 59 constitute a mere 16 percent of Botswana's de facto rural population and contribute only 24 percent of all income earning time. Women aged 20 to 59 constitute 27 percent of the population and account for 24 percent of income earning time. Boys aged 7 to 19 contribute time in excess of their proportion in the population, while the reverse is true for girls. In all, children and young ariults ( 7 to 19) account for 42 percent of all income earning time. However, there is a good deal of diversity between and within age/sex groups in regard to labor productivity and time allocations. In the sections which follow, we shall attempt to explain these diverse patterns.

\section{Some analytical problems}

Based on the theoretical framework pioneered by Becker (1965) and Wilis (1973), an individual's allocation of time to economic work may be viewed as a function of the household's unearned income, his own labor productivity and that of other family members, together with some relevant control variables. Increases in labor productivity should induce more economic work at the expense of other activities through a price effect. At the same time increases in labor procuctivity should reduce work time via an income effect. The latter expectation derives from the assumption that income increases raise the demand for leisure and such orher 'commodities' as child schooling and child rearing at the expense of economin work. At best, we can observe the net impact of labor productivity through both channels of causation. This problem limits the capacity of economic theory and analysis to predict time allocitions.

A further methodological problern concerns the characteristics of the labor market in rural Botswana. In many rural ecor omies a wage labor market exists, allowing households which are asset-poor to hire out some of their la'sor to houscholds, business firms, or government agencies which have larger holdiags of productive assets. The process of hiring labor out and hiring it in tends to equalize the marginal productivity of a given kind of labor throughout the rural economy. As we have seen, opportunities for wage labor are quite limited in Botswana, particularly for women and children. Data (not shown here) indicate that about half of the people who engage in wage labor are government employees, sales and construction workers, michanics, tanners, drivers, teachers, nurses, and the like, leaving oniy a small group which performs agricultural labor. Lucas (1981a), also using the RIDS data, found that only 1 percent of crop-producing households reported any expenditure on: wage labor. This figure does not include expenditures on plowing services reported by 17 percent of such households, often female headed.

A household which does not buy or sell labor may be called an autarchical household. The concept of an autarchical farm operation accords with a 
good deal of evidence from farm management studies in LDC showing that labor intensity and sutput per acre are inversely related to size of landholdings. ${ }^{5}$ Lucas finds the same to be true for crop production in Botswana. Autarchical modes of production imply tha asset-poor households often use family labor to a point where marginal returns from work are very low rather than hiring out their surplus labor to households with more resources which could use that labor more productively. Autarchical working arrangemenis may reflect a reluctance on the pari of small farmers to hire out family laior, high transport costs, a view on the part of larger farmers that hired labor is less desirable than family labor, or an institutionally determined agricultural wage which is too high to clear the labor market. ${ }^{6}$ In Botswana farm operations come close to being autarchical, especially as regards female and child labor. Adult men do migrate to South Africa and urban areas in Botswana, in substantial numbers, and this possibility affects the value of adult male time; but within agriculture relatively little adult male labor is hired in or out.

This issue is important because labor productivity can be viewed as a predetermined variable only when generated by a competitive labor market in which households buy and sell labor whenever marginal productivities deviate from the market wage. In a setting where autarchical modes of production predominate, as is the case in rural Botswana, a person's productivity depends largely on the complementary resources available in the household enterprise such as education (know-how), land, cattle, tools, etc. Moreover, the marginal productivity of labor is not observable.

The marginal productivity of labor is of interest not only because it influences time allocations but also because it may help us to evaluate how adequately the rural labor supply is utilized. There is no doubt general agreement that work having zero marginal productivity would signify surplus labor. However, zero marginal productivity is a polar case and should rarely be found in practice, except perhaps where somebody works for training, to keep busy, to keep up social appearances, to keep company - as may sometimes be the case among children in Botswana - or where certain activity-sharing arrangements have become institutionalized. Laborers doing work of very low productivity also may be regarded as being under-utilized, but there is no general accepted citerion for deciding how low productivity has to be to signify under-utilization.

The amounts of leisure time reported by different groups in different socioeconomic strata may be a partial indicaror of underemployment. In the analysis which follows we shall look for evidence of both low marginal productivity of labor and long hours of leisure tine as indicators of possible underemployment. This may enable us to deternine whether labor under-

\footnotetext{
${ }^{5}$ See for example, World Bank (1980, p. 42).

${ }^{6}$ For a further analysis of these issues see Berry and Sabot (1978).
} 
utilization exists, but it will not allow us to quantify its extent. Because time use data metsure only work duration without regard to work intensity, it is particularly mportant to view long leisure hours and low productivity as two related facets of labor under-utilization. Self-employed people who have little work to do may work more slowly or rest more often than those who are pressed to accomplish a great deal. People who are poorly nourished may be forced to adop: a slow work pace. In these cases the productivity of work time should indicate under-utilization, even if duration does not.

We shall now proceed in two steps. First, we shall calculate a household' enterprise production function and shall derive estimates of the marginal productivity of household labor, categorized by age and sex, from that function. Thus in step one we shall obtain information on the magnitude of marginal labor productivity and on the way in which time inputs, human and non-human, capital and certain control variables affect labor productivity. These results have a bearing on the underemployment issue.

Secondly, we shal estimate the allocation of time by individuals as a function of the variabi ss considered to be predetermined in our analysis education of adults, preductive assets, and demographic characteristics of the household. In this analysis education and productive assets must be viewed as proxies fo: productivity, i.e., as having price and income effects.

\section{Productivity of time}

For estimation purpo:es income of household $x\left(I_{x}\right)$ is considered nat of transfers. It is assumed to be generated by a production function where age/sex-speciic sime $\tau^{r(a, s)}$, human capital $\left(E a^{\prime}\right)$ and physical assets $(A)$ are inputs, in addition to a set of controls $(R V$. We thus estimate

$$
\ln l_{x}=a+b \ln \tau_{x}^{c(a, s)}+c \ln E d_{x}+d \ln A_{x}+e R V_{x}+\varepsilon_{x}
$$

The time inputs of households are here condensed into three categories: total working time of males aged 15 and above, of females aged 15 and above, and of children 7-14 (regardless of sex). Children 15-19, a relatively small group, are combined with adults since their efficiency in production should come close to that of adults. Also, the time use analysis will show some substitutability between the economic work time of young boys and girls, betweer men and older boys, and hetween women and older girls. The regressions vere also run with children divided by sex and with separate categories for time inputs by children 15-19. Instances where these more detailed breckdowns provide additional (or different) information will be reported in the text.

Before turning to the results, some limitations of the productivity estimates must be pointed out. First, income and time allocation are codetermined, but 
we do not have enough explanatory variables to identify a simultaneous equation system. The sinultaneity bias may lead to some underestimation of the time input coefficients. Second, land is not a major constraint on production in Botswana alihough quality of land may be, but we do not have a measure of land quality. Third, time use data based on a sample of only 5 days in the year do not have a high degree of precision. For these reasons the estimated coefficients must be viewed as indicators of orders of magnitude.

Since we are interested is productivity estimates for households which exhibit substantial variations in earnings opportunities, a few interactions are considered. We use first unly non-wage or self-employment income as a dependent variable, and exclude time spent on wage labor from the analysis. Then we add wages as pait of income and wage labor as part of the time inputs and re-estimate the same function. We also differentiate between households who own cattle ( 55 percent of households) and those who do not. A final distinction is made between households with at least one male and one female age 15-64 and households with no adult males (29 percent of all households). The various estimates of relationship (1) should enable us to assess the relative productivity of time inputs of the various categories of household members under different economic and demographic circumstances.

Table 4 presents the regression coefficients for all households which contain at least one women and one man of prime working age with selfemployme" $t$ income as dependent variable. The equation for all households explains 53 percent of the variance in in come, for cattle owning households 52 percent, and for households without cattl only 16 percent. The differences between the $R^{2}$ 's reflect the role of cattle ownership in the determination of agricultural income in Botswana.

The regression coefficients $(b)$ represent the elasticities of income with respest to the inputs inte the production function. Presumably a 10 percent increase in cartle ownership in cattle owning households would increase selfumployment income in these households by 6 percent. However, because of unavoidable shortcomings of the data and method, such precise inferences are not warranted. We can say that for all households and for cattle owning households, the value of cattle is the major determinant of income (as measured by beta or $t$ ). Ownership of smaller animals also has a significant effect on income, especially in households without cattle. Land seems to be impoitant only in households without cattle. Education enhances selfemployment income in householis without sattle, but not to any great extent. Residents of Baralong Farnis. the commercial farming area in th: sample, appear to have an advantage in generating income even among the

\footnotetext{
Another froblem is that Bots'vana has a strong tradition of mutual assistance among relatives in economic work. Thus some reported economic work may have been performed for other houselolds. It is unlikely that such practices affect our productivity estimates to an appreciable degree since working for others in most cases involves some reciprocity.
} 


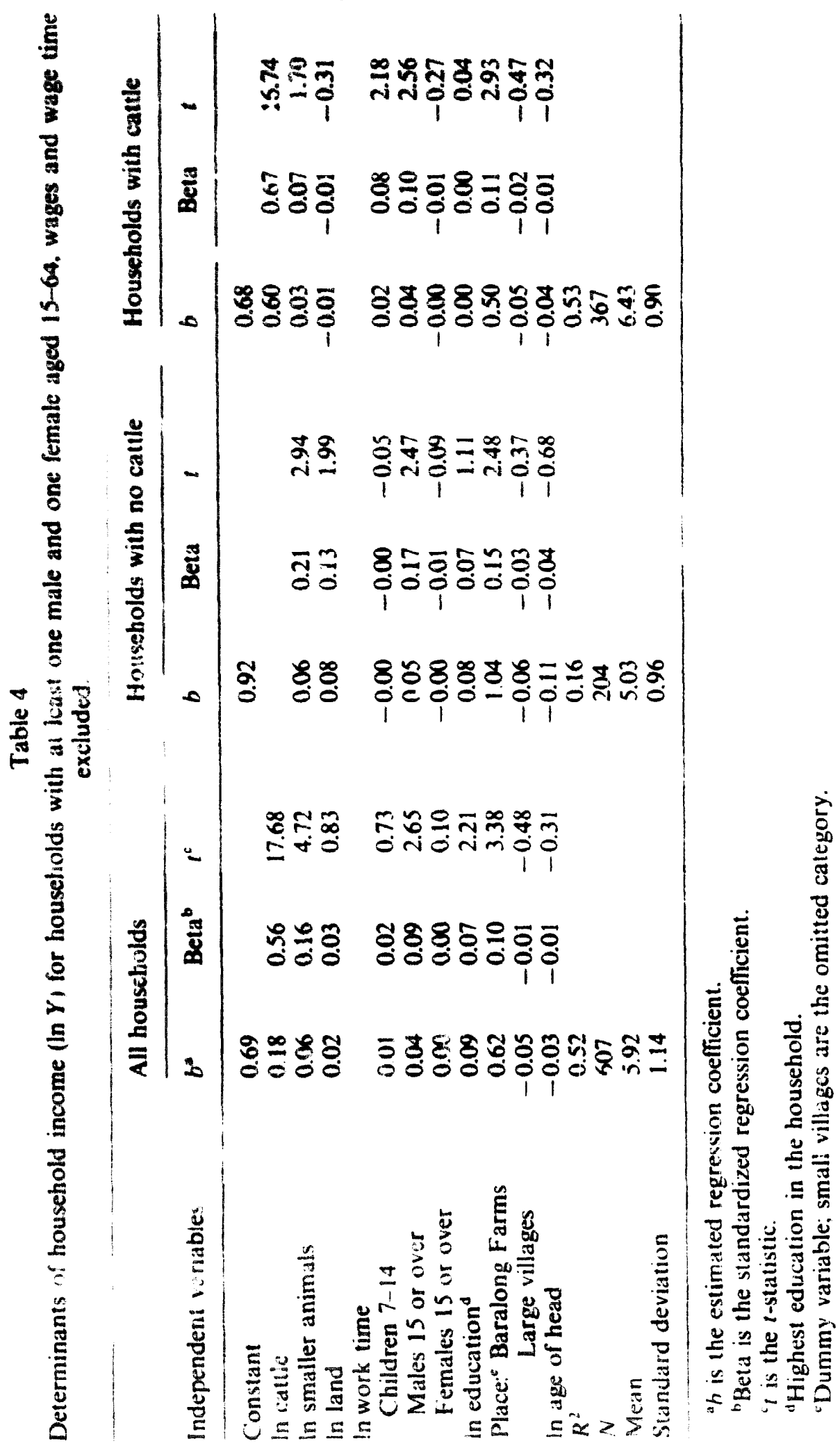


self-employed; all other things equal, they have higher incomes than residents of other areass.

As expected, adult male labor is a significant factor in the production process under all observed circumstances. Children's labor makes a significant contribution in cattle owning households only. Women's labor time doe, not prove to be statistically significant in explaining variacions in household income.

Table 5 presents coefficients with wages included in income, and wage work in working time. The importance of the education variable is greatly increased in this version. This result indicates that, while education has a moderate impact on earnings in self-employment, it has a major effect on the opportunities for wage work as well as the level of wages.

Location in a large village (as compared with a small village) offers no advantages for self-employment but improves access to wage work, especially the better paying wage jobs.

Animals and land are somewhat reduced in importance as sources of income when wage work is taken into account. The contribution of male labor to income rises substantially when wages and time worked for wages are included in the data, but this is not the case for women's and children's labor. This finding is in ac:ord with earlier evidence showing that men do more wage labor than wornen, and that children do practically no wage labor. The time inputs of children in cattle owning households remain significant factors in the geteration of household income; the time inputs of women and of children in households without cattle remain insignificant.

Tables 4 and 5 include only households which contained a prime working age male (15-64). Table 6 presents a similar anaysis for female headed households without prime working age males. Most of the results parallel those appearing in tables 4 and 5. The gieatest difference appears in the estimated contribution of time inputs of adult women to household income. In female headed households the economic work time of women has a significant effect on household inceme, especially when wage work is included. The work contribution of children is insignificant for the most part, probably because female headed households own fewer animals than households with male heads. Education has a sinailer positive impact in female headed households than in others because, as Lucas (1981b) has shown, female wage rates are less responsive to orucational atiainment than males' wage rates, and opportunities to obtain wage jobs also are more limited for women.

A number of alternative forms of the production function were calculated, including a linear form with and without interactions between hours worked and assets, separate equations for high, middle and low incom households, different age divisions, househo:d composition groups, and 1 : like. Such experimentati " is justified as iong as the results are viewed as a kind of 


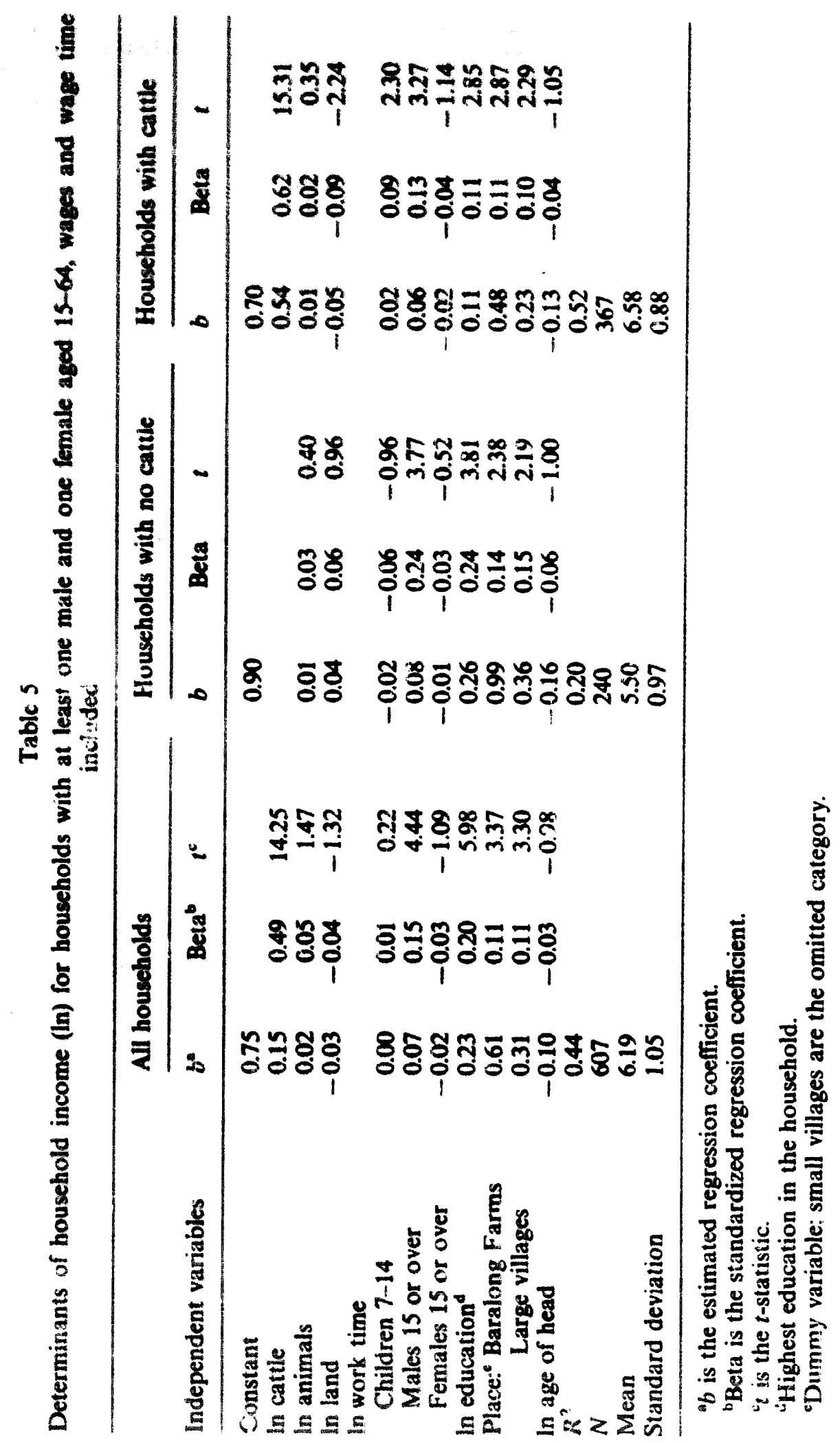


Table 6

Determinants of household income $(\ln Y)$ in female headed households (with no male ager 15-64).

\begin{tabular}{|c|c|c|c|c|c|c|}
\hline \multirow[b]{2}{*}{ Independent variables } & \multicolumn{3}{|c|}{$\begin{array}{l}\text { Wages and wage time } \\
\text { excluded }\end{array}$} & \multicolumn{3}{|c|}{$\begin{array}{l}\text { Wag ss and wage tir. } \\
\text { included }\end{array}$} \\
\hline & $b^{n}$ & Betab & $t^{c}$ & $b$ & Beta & $t$ \\
\hline Constant & 0.67 & & & 0.68 & & \\
\hline In cattle & 0.18 & $0.5^{2}$ & 8.88 & 0.16 & 0.49 & 8.20 \\
\hline In animals & 0.08 & 0.28 & 4.40 & 0.08 & 0.29 & 4.49 \\
\hline $\begin{array}{l}\text { In land } \\
\text { In work time }\end{array}$ & -0.02 & -0.03 & -0.52 & -0.06 & -0.10 & -1.72 \\
\hline $\begin{array}{l}\text { Children } 7-14 \\
\text { Males } 15 \text { and over }\end{array}$ & 0.02 & 0.05 & 0.93 & -0.02 & -0.07 & -1.13 \\
\hline Females 15 and over & 0.04 & 0.09 & 1.66 & 0.07 & 0.17 & 3.27 \\
\hline In education & 0.03 & 0.02 & 0.42 & 0.17 & 0.16 & 2.91 \\
\hline Place: Baralong Farms & 0.68 & 0.05 & 1.02 & 1.10 & 0.09 & 1.77 \\
\hline Large villages & 0.18 & 0.06 & 1.12 & 0.49 & 0.19 & $\mathbf{3 . 3 3}$ \\
\hline In age of head & -0.39 & -0.12 & -2.30 & -0.58 & -0.20 & -3.82 \\
\hline$R^{2}$ & 0.55 & & & 0.53 & & \\
\hline$N$ & 200 & & & 200 & & \\
\hline Mean & 5.02 & & & 5.29 & & \\
\hline Standard deviation & 1.11 & & & 1.02 & & \\
\hline
\end{tabular}

${ }^{a} b$ is the estimated regression coefficient.

'Beta is the standardized regression coefficient.

${ }^{c} t$ is the $t$-statistic.

${ }^{d}$ Highest education in the household.

'Dummy variable; small villages are the omitted category.

sensitivity analysis. The findings regarding the relation of time inputs to income were found to be quite robust. hiours of adult male labor always have a significant positive relation to income. Child labor inputs are significant in cattle owning households only. When boys' and girls' working hours are treated as two separate inputs, only the work contributions of boys in cattle owning households appear statistically significant. The regression coefficient for inputs of working time by adult women is significant only in female headsd households. ${ }^{8}$

Marginal productivities of work time were calculated from the regressions in tables 4-6. They may be expressed in Pula per day, assuming a 6-hour work day on the average. On this basis the marginal productivity of male labor comes to $0.18-0.22$ Pula per day, and the marginal productivity of female labor is slightly lower. These figures can be compared with daily wage rates to give the reader some perspective on the orders of magnitude

\footnotetext{
${ }^{8}$ In a similar study in rural Niger, based on more detailed time use data for each agricultural reration and each field, tránslog production equations were estimated with child labor inputs included. The results indicate that the effect of child labor (8-14 years olui) upon agricultural output levels was not significantly different from zero. However, female labor was infinitely substitutable for male labor and had a positive marginal productivity. See Thomas-Peterhans (1983).
} 
involved. As shown in Lucas, at the time of the survey the average daily wage in rural areas was 1.26 Pula for men without education and 150 Pula for those with 1-4 years of schooling; it was 0.54 Pula for women with 0-4 years of education. Thus the marginal productivities are for the most part much lower thas the daily wage. ${ }^{9}$ This is not surprising, considering the very limited opportinities for wage work and the strong seasonality of labor demand. At the time of the survey the average daily income per person in rural areas was about 0.35 Pula. Thus it is plausible that men would find it worth while to pursue work in their own enterprises which at the margin yielded the equivalent of only 0.18-0.22 Pula a day.

To summarize this section, it appears that non-human capital and to a lesser extent human capital are critical in the determination of productivity levels. In asset-poor households people are forced to undertake work of very low productivity. Particularly, women and children in such households seem to pursue income-earnings activities up to a point where the marginal return to their labor is close to zero. Because men have the option to migrate and male labor is relatively scarce, the marginal productivity of male labor is higher, even in asset-poor households.

\section{Determinants of time use}

The determinants of time use were estimated by means of regression analysis. The dependent variable for the analysis of ime allocation is $t_{i j}$, the amount of time spent by individual $i$ on activity $j .{ }^{10}$ Four categories of activities are considered: (1) economic work, (2) housework and child care, (3) schooling for age groups 7-19, and (4) leisure. Housework and child care are combined since they are often concurrent activities. The unit of measurement for time allocation is total number of minutes spent on each activity category summed over the five days.

The independent exogenous variables include human and non-human assets, and demographic characteristics of the household. i hese variables are entered additively into the estimating equation:

$$
I_{i j}=a+b E d_{i}+c E d_{x}+d A_{x}+e I_{u x}+f R V_{x}+\varepsilon_{i j}
$$

By estimating the linear model and using the same explanatory variables for each of the four ime uses, one can compare the regression coefficients across equations to observe possible substitutions between one time use and another. ${ }^{11}$

\footnotetext{
${ }^{9}$ The same result was o tained in Niger. See Thomas-Peterhans (1983).

"If one were to analyz 2 time inputs on a amily basis, one would have to add time inputs of men, women, and childre $n$, using assumed $\mathrm{l}$ oductivity weights. This would be less meaningful than to look at each age/sex category separately.

${ }^{11}$ Total activity time does not add to the same number of hours in each household, sin:2 eating and sleeping were omitted. However, there is a fairly narrow dispersion around a mean of 12 hours.
} 
As noted earlier, asset holdings aci in the regressions as proxies for both earned income and price effects. The assets of household $x\left(A_{x}\right)$ included are value of cattle, value of small animals, and area of lind cultivated. ${ }^{12}$ Data on equipment owned were collected, but they are too highly correlated with other assets to be useful in the analysis. The ownership of human capital is represented in this section by two measures: (1) the education of the person whose time allocations is being analyzed $\left(E d_{i}\right)$, and (2) the highest education among adults in the household $\left(E d_{x}\right)$. Transfer incomes $\left(I_{u x}\right)$ are the only directly measured source of income that is entered into the equation as : predetermined variable.

Household size is represented by a series of variables reflecting the size of each age/sex group. This permits different kinds of household members to influence time allocation differently. The remaining independent variables control for age and village characteristics. Separate equations are estimated for males and females 20-64. Children 7-19 also are divided by sex since the sexual division of labor leads boys and girls to pursue quite differen activities. Young people aged 15-19 are here grouped with children rather than adults since, like children, (1) they do very little wage labor, and (2) they still show a fair amount of school attendance. Initially separat: regressions were run for age groups 7-14 and 15-19 but findings were quit: similar. Hence for the sake of brevity, the younger and older children of each sex are combined, with a control for age among the explanatory variables.

The results for adult men are presented in table 7, for adult women in table 8, and for boys and girls in tables 9 and 10 respectively. School time is not shown in the first two tables since adults rarely go to school in rural Botswana; at most they receive some religious or agricultural instr'sction. FCr adults, economic work is divided into two components, wage work and nor:wage economic time, bicause we expect the independent variables to have quite different relations to these two subcategories. Wage time is measured by the more complete series on wage labor (obtained in 12, rather than 5 survey rounds) and refers to days worked during the entire year instead of minutes worked on the five sample days. Since children rarely work for wages, the wage equations are omitted in tables 9 and 10 .

The education coefficients show that the more educated males spend more time in wage labor and less in self-employment than males with less education. This result is consistent with our earlier finding that education enhances productivity in wage employment much more than productivity in seif-employment. The education effect on adult females' time allocation is similar, except that women reduce housework in favor of wage employment. In some cases servants may help with the housework in the most educated

\footnotetext{
${ }^{2}$ The data on land holdings are weak; for about one-third of households it cannot be determined whether they had 1:0 land or whether they had land but the area was unknown. Further, no information is available on land quality or value. It is quite possible that larger holdings are of poorer quality than smaller holdings.
} 
households. For adults of both sexes, leisure time is not iignificantly influenced by education. It appears that the negative effect of ediucation on leisure via higher labor productivity and the positive effect of education or. leisure via bigher income roughly offset one another.

Boys who spend more time in school devote less time to economic work, while girls to less housework; children of both sexes also reduce their leisure time. The findings that in the more educated households boys do more housework probably implies that boys substitute to some extent for their sisters who spend at least as much time in school as they do. In total children's economic work is more significantly reduced by school attendance than are housework or leisure, although the latter activities are curtailed appreciably.

The hizher the level of livestock ownership, the more time adult males devote to farming and the less time they devote to wage employmcnt. Large landholdngs induce only a small increase in male time spent on farm activities, since crop cultivation is largely 'women's work'. In the case of women, total economic work requires more time in households with large landholcings than in those with smaller holdings. Landholdings and large herds of smaller animals reduce wage time. Leisure time of males is quite insensitive to holdings of productive assets, as it is to education. Again we infer thit price-of-time and income effects offset one another. Leisure time of women, on the other hand, is reduced on balance when landholdings are relatively la:ge.

As predicted by the earlier productivity analysis, cattle ownership has a very strong positive effect on the economic time inputs of boys 15-19 years of age, somewhat weaker for the younger boys (not shown separately in table 9). Th: economic work time of younger boys is positively and significantly correlated with holdings of smaller animals, which are typically herded by them. For boys the productivity effect of animal ownership clearly outweighs the income effect. The economic work time of girls also is positively related to ow'nership of smaller animals, for which they sometimes help to care. Since girls do not herd cattle, only the negative income effect of cattle ownership on work time is evident. However, in cattle owning households girls do more housework, thereby relieving their brothers from domestic obligations.

Tre relation beiween landholdings and children's work is weaker and less consistent in ign than is the cuse for animal holdings. In the case of girls, larger landholdings seem to be associated with more housework, presumably freeing the nother for crop cultivation. In this indirect way, large lancholdings enhance the economic role of girls and shorten their leisure hours.

Schooling time of boys is curtailed ver: significantly by ownership of smaller anintals, while larger cattle holdings signify high income and hence a stronger positive income effect on schocling. Since the marginal productivity 


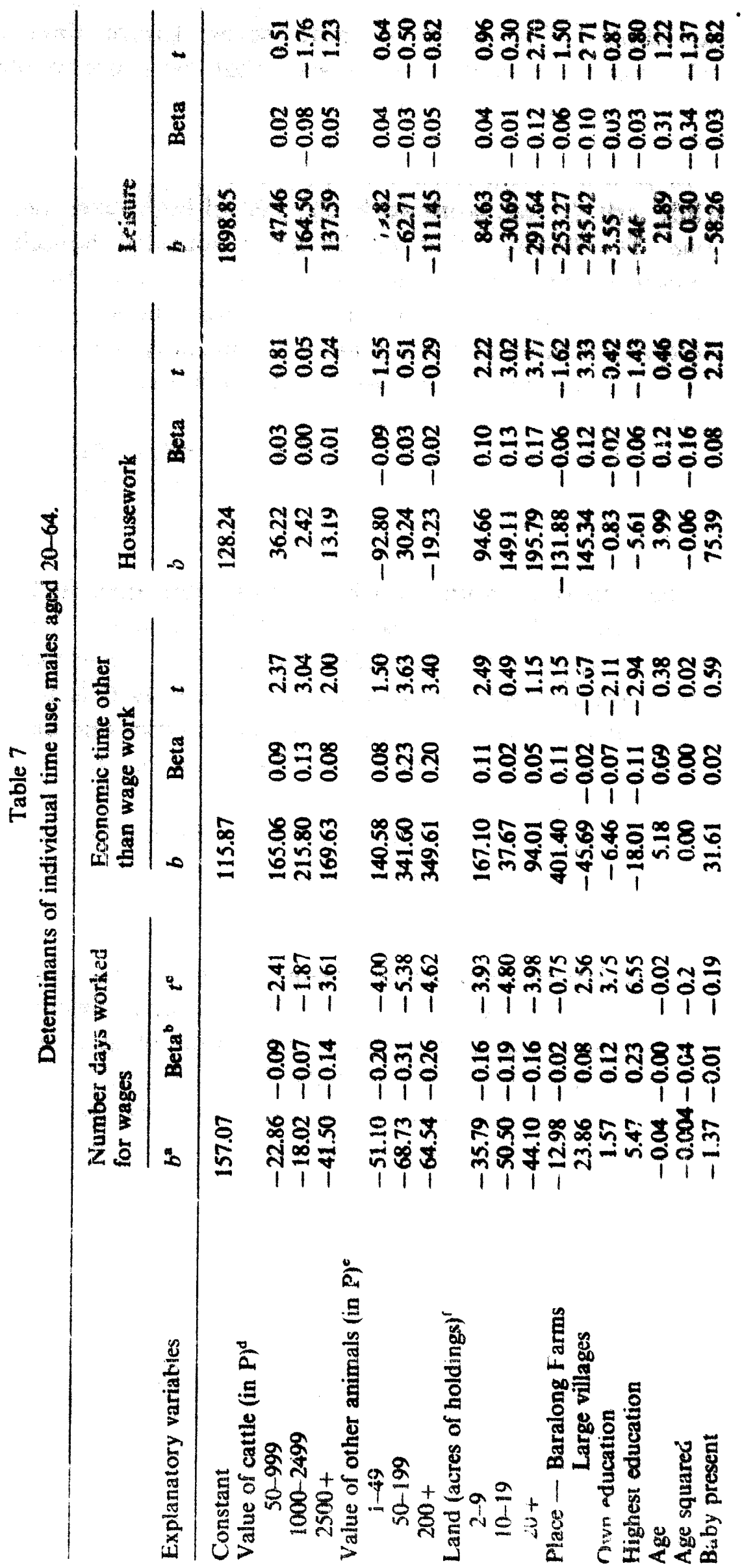




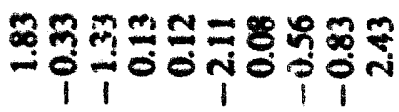

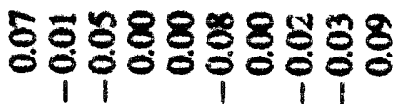

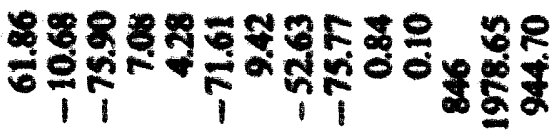

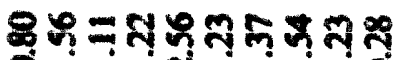

IT-

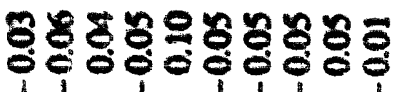

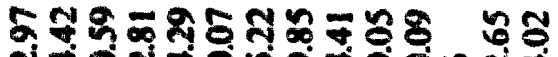

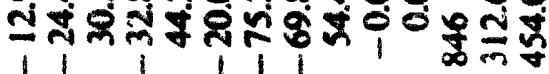

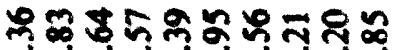

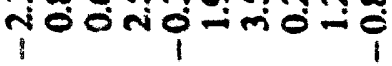

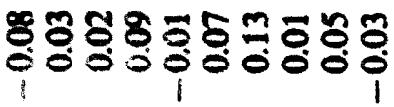

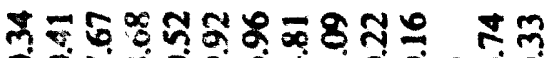

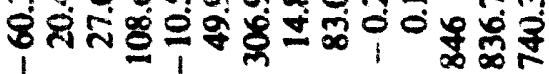

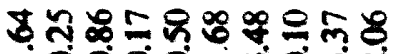

Ti TiTTiT

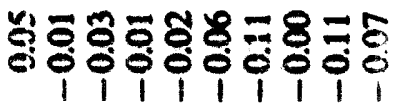

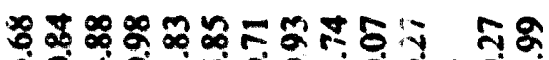

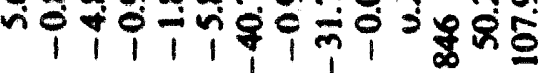
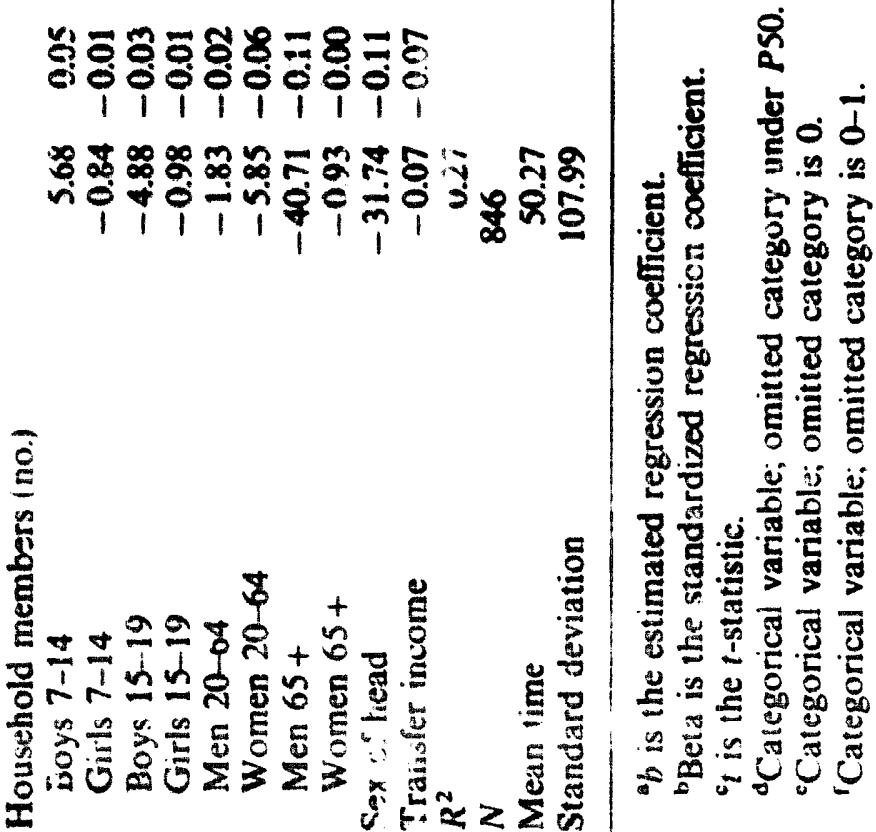


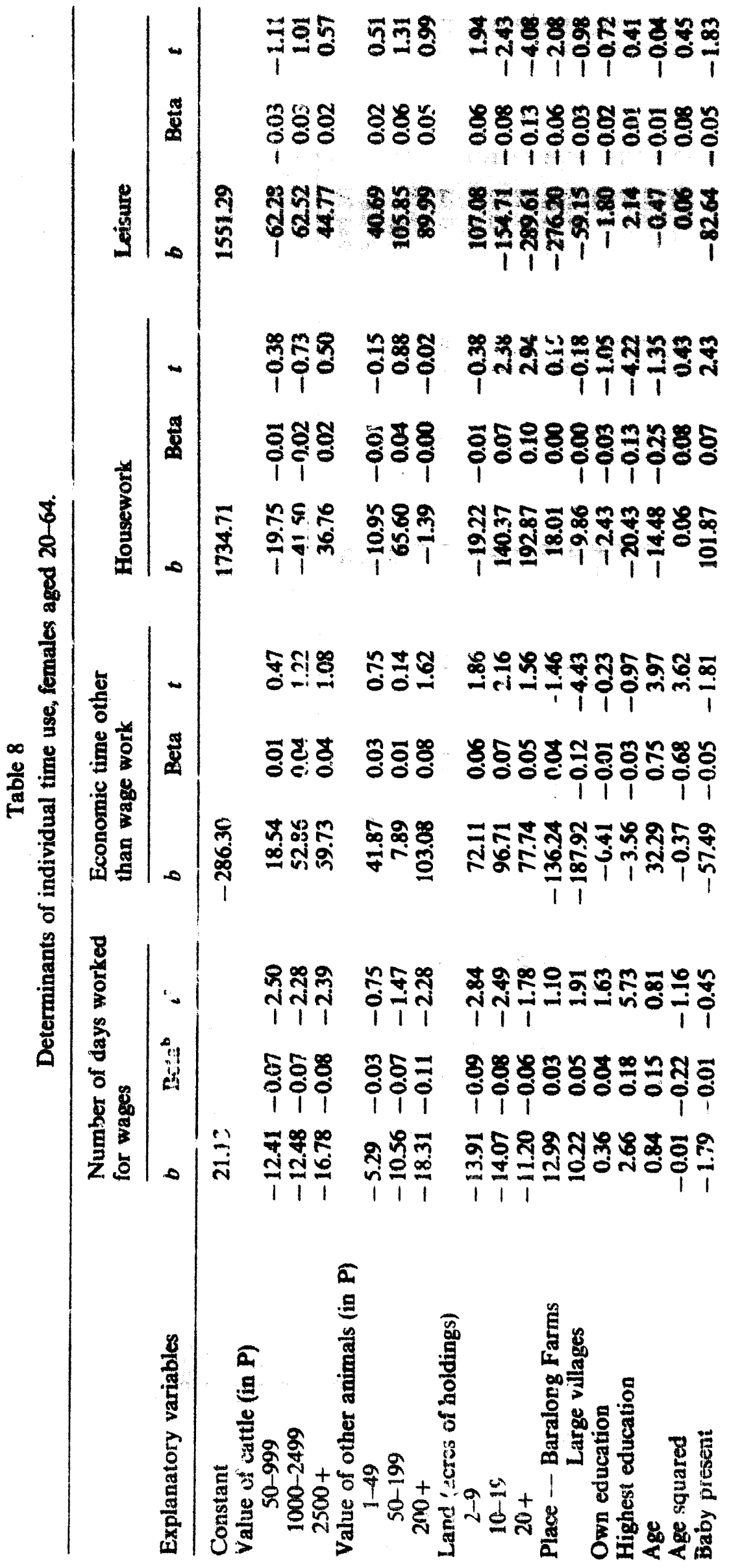




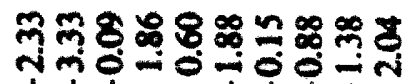

Tिi-OTiT

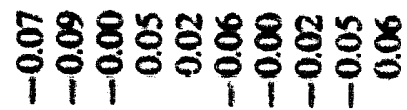

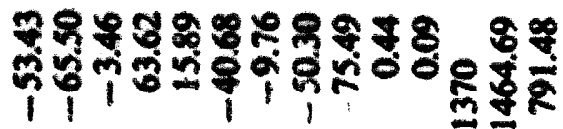

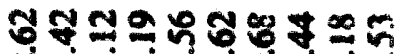

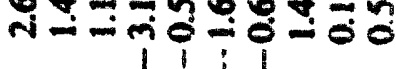

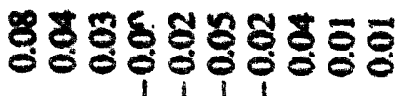

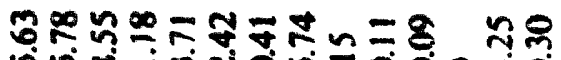

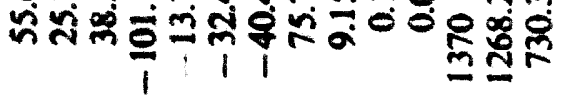

ตำรㅇำำำำ

1 -

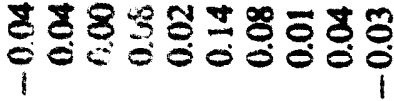

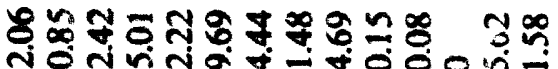

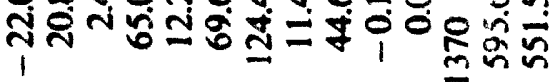

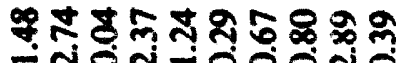

TONTITONO

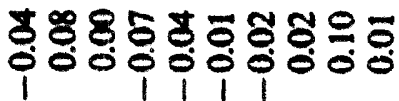

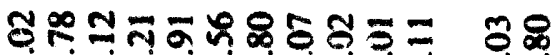

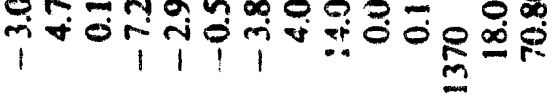

宫 


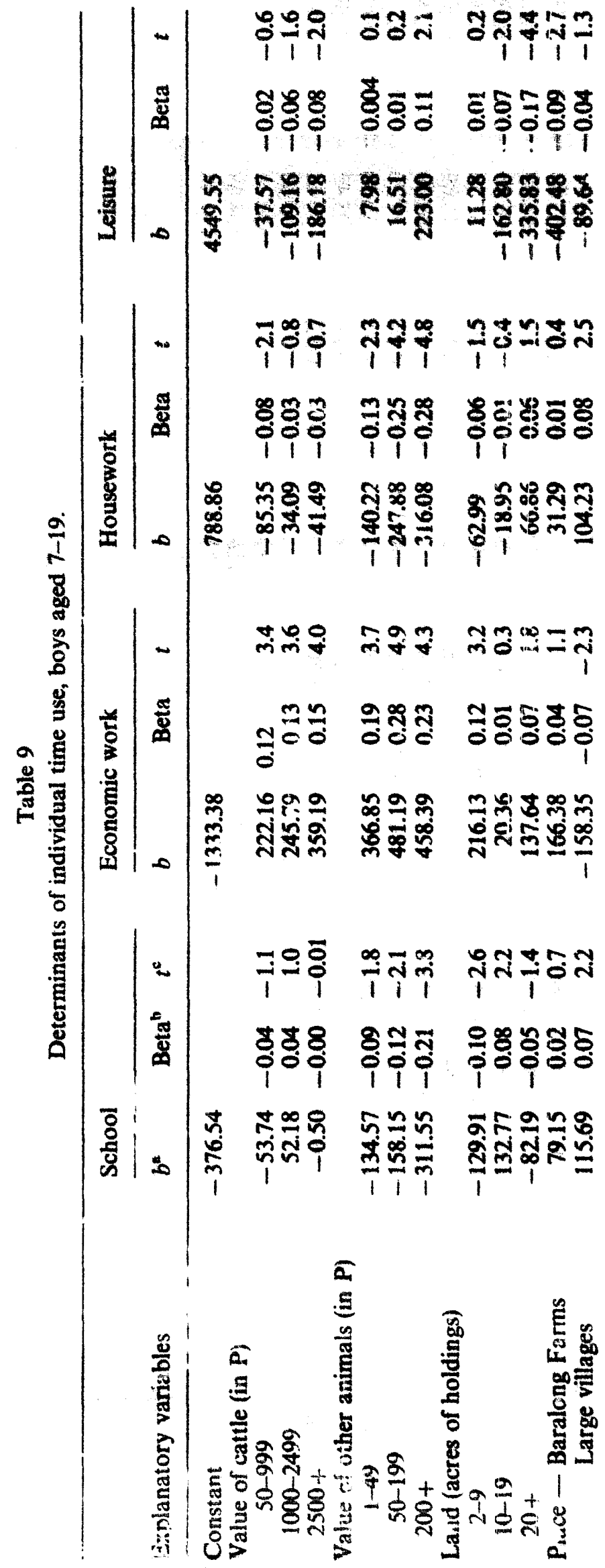




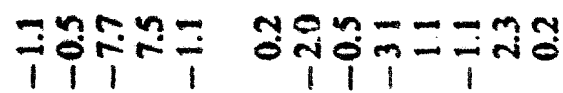

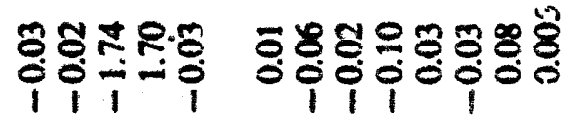

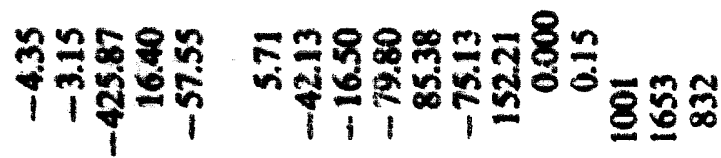

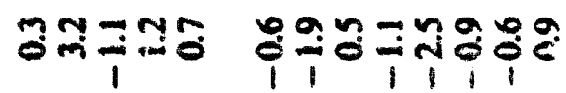

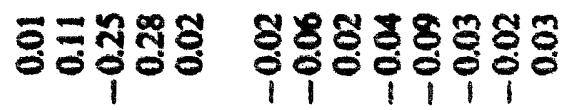

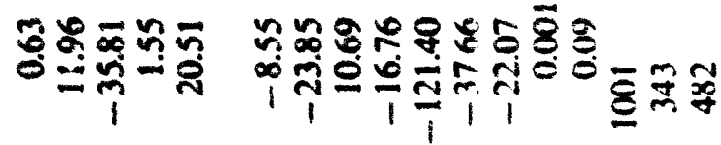

m̄nñivio

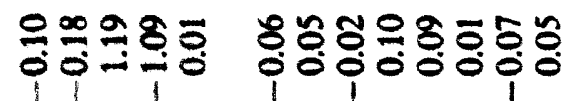

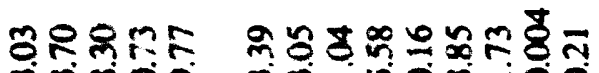

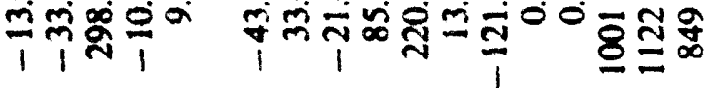

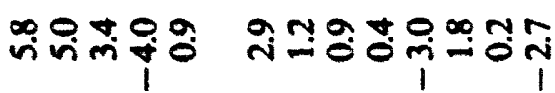

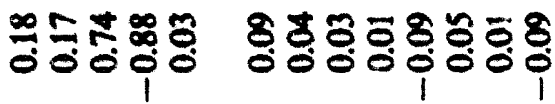

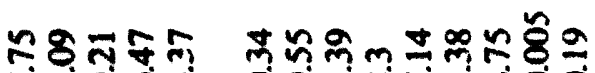

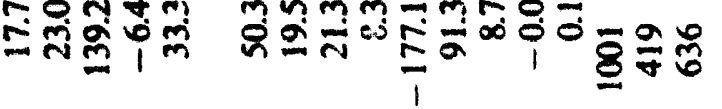
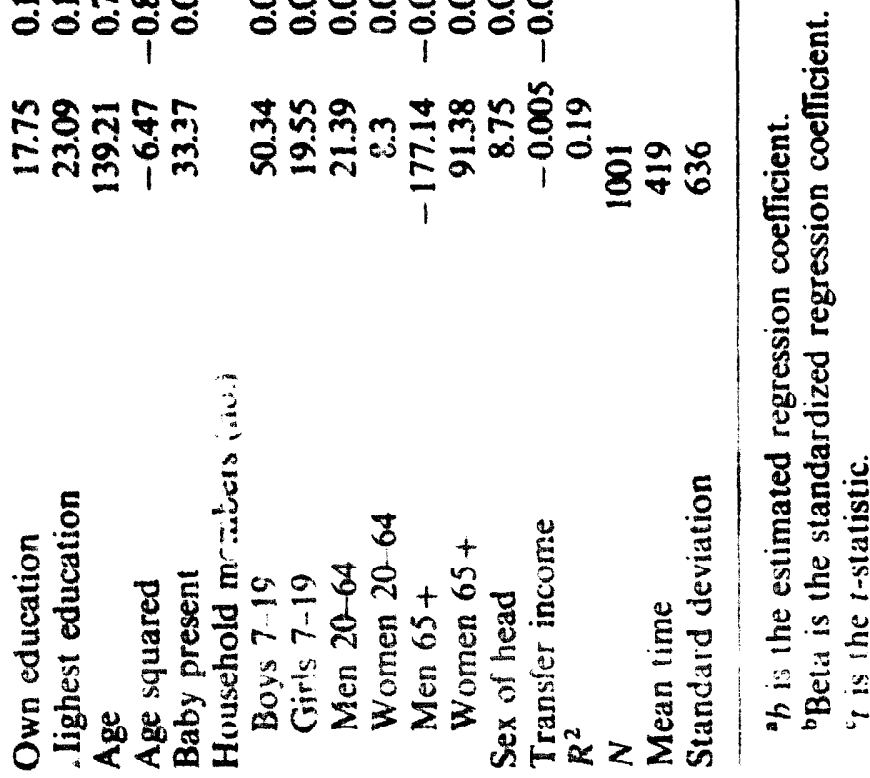


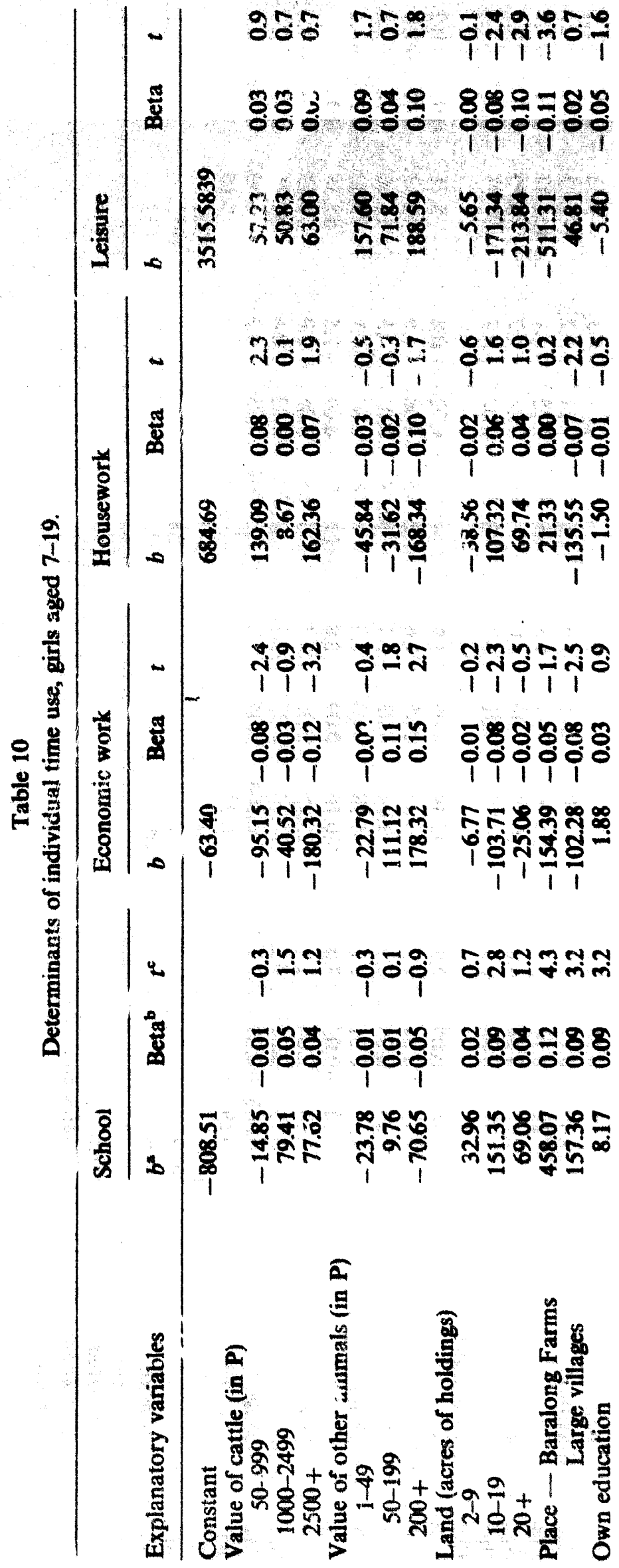




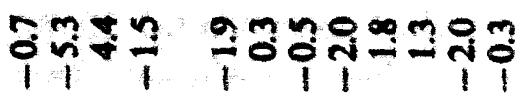

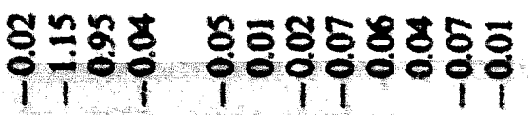

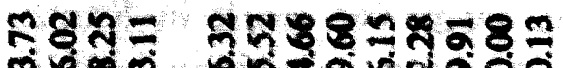

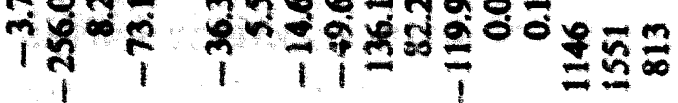

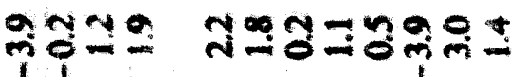

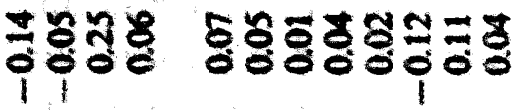

รั78ะ

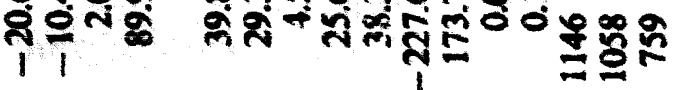

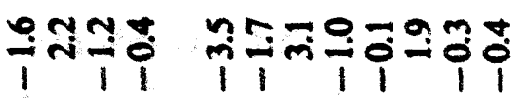

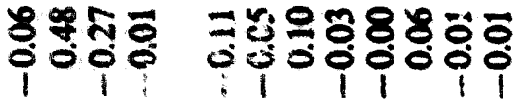

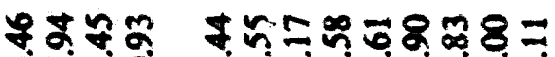

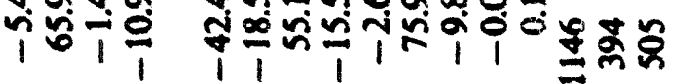

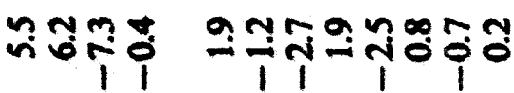

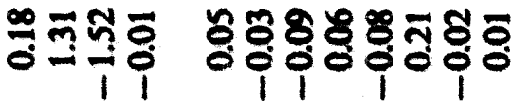

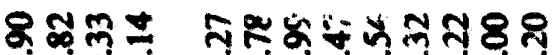

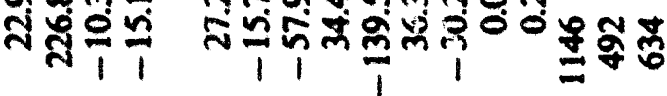
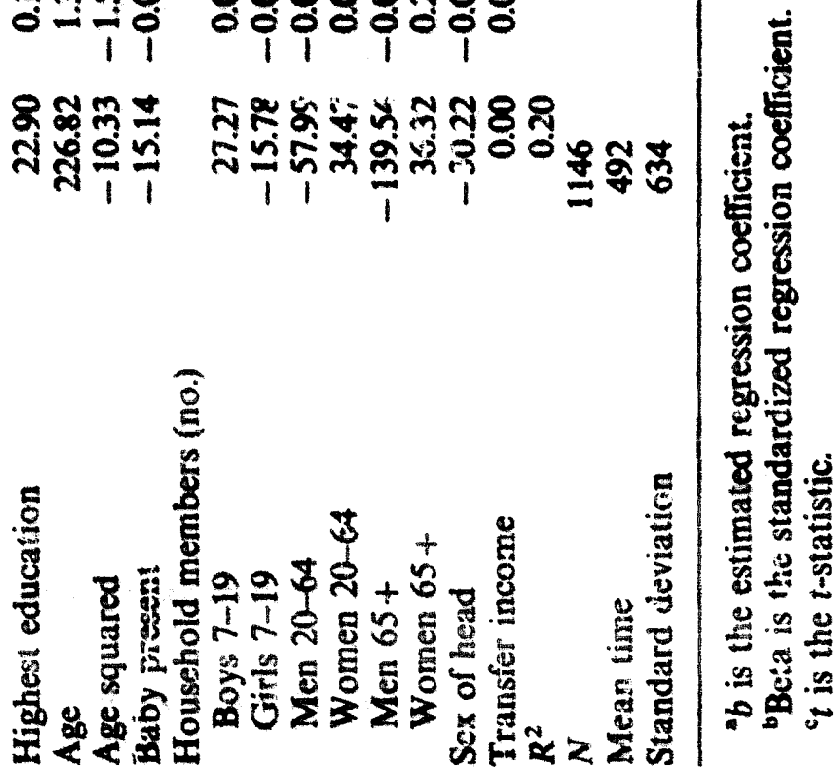
of girls in economic work is low, it is not surprising thit assets tend to be positively related to school attendance (via the income effect), although this relationship is not very robust.

Transfer incomes are normally erpected to produce a pure income effect. This is not necessarily the case in Botswana since a substantial part of transfer income comes from adult males who are away for work in South Africa or the towns of Botswana. Thus there may be some selectivity bias in that households with low labor requirements are more likely to have outmigrants. On the other hand, a "displacement effect" may occur whereby, all other things being equal, family members who are left behind must substitute in economic or household work for the absent member. The estimated coefficients indicate that, as the level of transfer incomes rises, economic work by adult men as well as women decreases and leisure increases. By contrast, displacement seems to affect boys; as transfer incomes rise, boys do more economic work, apparently at the expense of schooling.

We turn now to the variables which reitect the household's demographic characteristics. Age is measured in the equations by actual age and the square of its value. For adult males we cannot detect any age pattern in time allocations from our cross-sectional data. In contrast women's economic work increases up to about age 42 , as child rearing gradually occupies less time. After 42, aging reduces market work and household work and increases leisure. Not surprisingly children's economic time increases with age and ther levels off, while the opposite is true for leisure time. School time peaks around age 11-12.

A baby in the household is expected to make added demands on the mother's housework time (which includes child care) and that of other household members who can assist her. Indeed, the amount of time allocated to housework hy each woman aged 20-64 is raised modestly when a baby is present, while leisure and economic work are reduced. As just noted, an additional effect of childrearing on women's time allocations seems to be captured by the age variable. Girls likewise spend more time on housework and have less leisure when there is a baby in the househcld. Men's leisure time is curtailed somewhat under these circumstances, while housework time and economic work time rise (the latter not significantly).

In female headed households women spend more time on economic work than do women in male headed households, largely at the expense of leisure. Female headed households have lower incomes than male headed households and, as we saw earlier, the lack of male lavor in these households raises the marginal productivity of women's work. Tu some extent women substitute for the missing male labor. Table 8 also shows that female headedness is associated with more wage labor by women, probably a consequence of the low level of resources for self-employment (perhaps not fully captured by our asset measures). Boys in female headed households do less economic work and have more leisure than boys in male headed households, in full 
consistency with the relatively limited opportunities for self-employment in these households. Girls, on the other hanc', do more housework and have less leisure time. apparently substituting for their mothers.

Household composition effects may be measured by the number of household members in each age/sex category or by a single variable representing household size. These measures were used in alternate equations, but only r $:$ sults based on the more detailed measure are shown in the tables. Three findings stan! out when the household size variable is used: (1) the larger the household, the less leisure time each nember has. This result is consistent for men and women aged 20-64, and children 7-19 of both sexes and is statistically significant for each age/sex category. It suggests that in large households, which tend to have more dependent members (young children and old people), others have to work harder to provide sufficient income and lousehold services. It also suggests that after controlling for assets, there are no important economies of scale in household size. (2) The larger the household, the more time each man, woman, and boy devotes to work in the family enterprise, but not to wage work. This finding is closely related to the previous one and probably has the same explanation. It also reinforces other indications that wage work is not readily available to households which have a particular need for it. (3) The larger the hou'sehold, the greater is the specialization of children's functions along sex lines. In the larger housenolds, boys show more school attendance and more economic work but less houschold work, while girls do more household work and less economic work. In the smaller households, where the labor supply from children may not be well-balanced by sex, there is more flexibility in the sexual division of labor.

The variables which represent number of members in each age/sex group provide some further insights into substitutability between household members. For example, when there are girls 15-19 in the household, they share the housework with their mother. The consequent reduction in housework per adult woman frees up time for economic work. On the other hand, children under 15, young males 15-19, and to a lesser extent, elderly people increase domestic obligations per woman.

Boys are substitutes for each other and, to sorne degree, for men. The reduction in market work per boy which occurs as the number of boys and adult males in the houschold increases is balanced by an increase in school time. Apparently the demand for boys' labor, although substantial, is limited by the household's asset holdings so that families with more than one boy may send one of them to school while one or iwo others care for the animals and perform other necessary chores. Economic work per gill also decreases as the number of siblings increases leaving each girl more time for housework and schooling. This finding confirms the view that there is a limited demand for economic woik by children, and that girls are substitutes in economic work for each other and for boys. 
As regards location, men and women in larger villages appear to have more opportunities for wage labor and receive higher wages than their counterparts in smaller villages. Men show more agricultural work in Baralong Farms (along with higher labor productivity) than elsewhere at the expense of household time and leisure. Place of residence also has some impact on the time allocation of children. School attendance is greater in larger villages than in smaller places for both boys and girls. In the Baralong Farms area boys (like men) are heavily involved in agricultural work. As a result of this work together with relatively high school attendance, leisure hours are substantially shortened. In :he lar ger villages there seems to be less economic work available for childre? than in the smaller ones, so that more frequent school attendance does not impinge significantly on leisure time.

\section{Discussion}

Our findings are consistent with a number of hypotheses advanced in the theoretical literature. These hypotheses imply that time allocations are influenced by economic incentives, i.e., income and price-of-time effects. To be sure, our data did not permit a statistical separation of income and price effects, which usually operate on time use in opposite directions. Yet, in a number of instances where one effect could be assumed to be weak relative to the other, the stronger sifect showed the expected impact on time allocations.

The analysis of time allocations clearly shows that time devoted to economic work, comprising self-employment and wage-employr.uent, responds positively to the household's human and non-human capital. The more productive capital the household has, the more economic work its members perform, particularly its male children. Thus the productivity effect of capital on economic work outweighs its income effect. ${ }^{13}$ And even though asset-poor households are forced by their low income to engage in work of low productivity, there is no evidence of a backward bending supply curve of labor, i.e., of the income effect outweighing the productivity effcct.

At the same time we found strong evidence that in rural Botswana time allocaiions are constrained by a culturally determired division of labor by age and sex. In order to adhere to this division of labor, households may adjust their mix of assets in accordance with the available labor supply; for example, they may buy or sell cattle. Also, household composition is quite fluid in rural Botswana and may be adjusted (by migration, especially) to fit asset holdings. Such changes over time are known to occur but coulu not be documented on the basis of our cross-sectional data set. However, we did see evidence of some flexibility in the sexual division of labor. When households

\footnotetext{
"De Tray, anaiyzing ime use in rural Malaysia, likewise found no evidence that poor chiliren work longer hours than more well-to-do children; rural farm income there had no effect on children's working hours.
} 
have an unusual demani for the economic work time of a particular kind of labor, say adult female:s. other household members will substitute at the margin for that person in housework and economic work. Likewise, when a household lacks a particular category of labor, say adult males, ot'ier household members will perform some of the work that would normally be assigned to the missing category of labor. In sum, the RIDS data show that time allocations are subject to traditional norms and at the same time are responsive to some cegree to income and price effects.

Our estimates of the marginal productivity of work time can only be viewed as approximations since data quality and statistical procedures are subject to a number of reservations which have been discussed at some length. The robustness of the conclusions nevertheless suggests that our major findings are valid. In Botswana the marginal productivity of work time in rural self-employment is very low. People with small holdings of productive assets may be forced by their poverty to pursue some work which adds only minimally to income. They may also slow their work pace in ac-ord with the available time or in accord with their nutritional status. The marginal productivity of some time inputs by children are close to zero (although average productivity is no doubt positive). The productivity of adult male labor, of women's labor in female headed househ slds, and of children's labor in cattle raising households is positive and significant at the margin. althcugh quite low. This general result has important implications for emiployment policy even if the calculated regression coefficients and marginal productivities are not precise.

Labor underutilization is a major issue in Botswana. It is difficult to define the concept of surplus labor, especially in the case of women and children. We have used a purely operational concept, viewing as 'surplus' any labor which does not make a statistically significant marginal contribution to household income. We have also compared the amounts of leisure people have under various economic and demographic conditions. Our findings are consistent with the widely held view that, except during the busy season. there is substantial surplus labor in the rural areas of Botswana. The incidence of under-employment varies, however, by age, sex, and asset position.

The inference that there is underutilized adult male labor rests on several findings. First, we saw that reported leisure time for adult males is higher than the leisure time reported for women and for children 10-19; adult males have as mich leisure as children 7-9 years of age. Second, aslult males work 60 percent longer during the busy season than during the sl tck season, and almost the entire seasonal differential in working time is nal nced by leisure. Third, adult males work about a third longer in the comn ercial Baralong Farms area than in other places. And finally, we saw th t the marginal productivity of male labor is much lower than their market wige, suggesting that some men are forced to undertake work whicis contributes only very 
modestly to household income. This seems to be the case particularly in the slack season and for men in asset-poor households.

It must be recognized that the advantaged position of adult males with respect to leisure may represent one of several facets of male privileze in the Botswana culture. Therefore one must be cautious in inferring that male labour is underutilized. Still as Mlyrdal (1968) has suggested, it is unlikely that cultural norms regarding time use will survive if they are grossly inefficient economically.

Of course, the high male migration rate out of rural aress also suggests that there is a surplus of male labcur. However, we do not find a surplus of male labor in the Lewis or Fei and Ranis sense, where out rigracion leaves rural production unaffected. The opportunity cost of men's time in rural Botswana may be quite substantial during the busy season and seems to be positive, though low, at other times. Moreover, according to Kossoudji and Mueller (1983), the absence of male labor handicaps the income earning effort of female headed households.

While out-migration removes some of the surplus of male labor from the countryside, the migration rate of women is only about one-fourth that of men. The sexual division of labor and child rearing obligations prevent women's labor from being a close substitute for male labor. We found no evidence in numerous formulations of the productivity aralysis that the marginal productivity of women is positive and significant cxcept in female headed households. In the slack season women work only about a third as much as in the busy season, yet their housework time barely increases at all. Thus, it appears that even in the busy season women are not so hard-pressed that they are forced to cut corners on housework and child care. If both house;work and market work are taken into account, women work about 25 percent longer than men. Yet, due to the seymentation of the labor market and the low productivity tasks assigned to women, the labor of women may be even less effectively utilized than the labor of men.

About 70 percent of the increase in women's home time associated with the presence of a baby is balanced by a reduction in leisure, while the curtailment of women's economic work and girls' leisure is modest. Given this finding together with the finding that in male headed households the productivity of women's work is not significant at the margin, it would appear that in rural Botsivana the cpportunity cost of wome 's time is not a weighty deterrent to fertility. This inference is corsistent with stated desires for a large number of children. The only qualification is that babies need to be cared for in the busy as well as ihe slack season, so that there are bound to be occasional periods in some hcuseholds when child care interferes with rewarding economic work.

Children, especially boys tend to report long working hours in rural Botswana. No doubi, children's work makes a significant contribution to household welfare, but our dat suggest that more child labor is available 
than can be used productively. Evidence for this conclusion is provided by the insignificant marginal ;roductivity of children's labor in householfs without cattle and the absence of a market for chiid wage labor. in Baralcng Farms, where adult males are engaged in commercial crop cultivation, boys work much longer hours in animal husbandry than in other villages without reducing their schooling, suggesting that there may be excess leisure in other places. Another piece of evidence may be found in the negative partial correlations between the work time per child and the number of children in the household. Further, if adult female labor is used in marginally productive work, women could probably do with less assistance from daughters in housework and child care.

One may then wonder why children work such long hours and often do not attend school. Part of the explanation may lie in measurement problems. Time use data do not take account of the intensity of work. If sume children intersperse their work with play, reported working hours may be inflated. Another part of the explanation may lie in social customs regarding work sharing, parents' desire to train and socialize children for adult responsinilities, and possibly the value parents attach to their own leisure. Finally, we must remember that there are great variations among households in the economic wortstine of children and that these are related to asset holdings. Quite clearly, households which are well endowed with productive assets berefit from the labor of their children, while this is much less true for poor houscholds. This finding has important implications for the process of income determination and for fertility decisions. Chernichovsky (1981) has shown that in rura! Botswana well endowed households do indeed have more children.

\section{References}

Becker, Gary S., 1965, A theory of allocation of time, Journal of Political Economy 75, 493-517.

Berry, A. and R.H. Sabot, 1978, Labour market performance in developing countries: A sur yey, World Development 6, especially 1222-1228.

Bond. C.A., 1974, Women's involvement in agriculture in Botswana, Mimeo. (Gaharone, Botswana).

Boulier. Bryan L., 1977, Children and household economic activity in Laguna, Phillipines, Journal of Phillipine Development IV, no. 2, 195-222.

Byerlee. D. and C. Eicher, 1979, Rural employment, migration and economic development, African Rural Employment paper no. 1 (Michigan State University, East Lansing, MI).

Chernichovsky, 1981, Socoeconomic corfelates of fertility behavior in rurai Botswana. Population and Humin Resources Division, Discussion paper $\$$ 1-48 (World Bank, Washington, $\mathrm{DC}$ ).

Cieave, J., 1970, Labour in the development of African agriculture, unpublished Ph.D. thesis (Stanford University. Stanford, CA).

Da Vanzo, Iulic and Donald L.t. Lee, 1983, in: Mayra Buvinic et al. eds., Women and poverty in the third world (Johns Hopkins University Press, Baltimore, MD)

D: Tray, Dennis, 1982, Chidren's economic contributions in Penninsular Malaysia, Working draft. Mimeo. (Rand Corporation, Santi Monica, CA). 
Everson, Robert E, B.M. Popkin and E. King Quizon, 1979, Nutrition, work, and demographi, kethavior in rural Philippine households, Bornomic Growth Center discussion paper 378 Y Yale University, New Haven, $\mathrm{CO}$ ).

Hart, Gillian, 1981, Falterns of household labor allocation in a Javanese village, in: Huns P. Bi uswanger et al., eds., Rurai household studies in Asia (Singapore University, Singapore).

Korsoudji, S. and E Mueller, 1983, The economic and demographic status of female headed itouseholds in Botswana, Economic Development and Cultural Change 31, no. 4.

Lipton, Michal, 1978, Employihent and labour use in Botswana: Final Report, 1 , Ministry of Finatice and Development Plansing (Government of Botswana, Gabarone).

Lucas, Robert E. B. 1981a. The distribution and effieiency of crop production in tribal uraen of Botswana, Population and Human Resources Division, Discussion paper 81-45 (World Bank, Washington, DCI).

Lucas, Robert EB., 19816, The distribuion of wages and employment in rural Botswana, Population ini Human Resources Division, Discussion paper 81-46 (World Bank, Washington, BD).

Myrdal, Gunnar, 1968, Asian drama (Pantheon Books, New York).

Thomas-Peterhans, R.S., 1983, The stratification of the production and marketing of livestock in Southem Niger in the Department of Zinder, unpublished Ph.D. thesis (University of Michigan, Anr Arbor, MI).

Willis, Robert J., 1973, A new approach to the economic theory of fertility behavior, Journal of Political Economy 81, no. 2, 11, 514-56:

World Bank, 1980, World development report (Oxford University Press, New York) 42. 